https://helda.helsinki.fi

The importance of evidence-based enhancement of the quality of learning and teaching in research-intensive universities

\title{
Lindblom-Ylänne, Sari
}

Palgrave Macmillan

2017-08

Lindblom-Ylänne , S \& Breslow , L 2017 , The importance of evidence-based enhancement of the quality of learning and teaching in research-intensive universities . in B Stensaker, G T Bilbow , L Breslow \& R van der Vaart (eds), Strengthening teaching and learning in research universities: Strategies and initiatives for institutional change ., 8, Palgrave Macmillan, Cham, Switzerland , pp. 187-213 . https://doi.org/10.1007/978-3-319-56499-9_8

http://hdl.handle.net/10138/310602

https://doi.org/10.1007/978-3-319-56499-9_8

unspecified

acceptedVersion

Downloaded from Helda, University of Helsinki institutional repository.

This is an electronic reprint of the original article.

This reprint may differ from the original in pagination and typographic detail.

Please cite the original version. 
Book chapter in B. Stensaker, G. Bilbow, L. Breslow \& R. Van der Vaart (Eds) Strengthening teaching and learning in research universities: Strategies and initiatives for institutional change. Dham, Switzerland: Palgrave Macmillan, 187-213. ISBN 978-3-319-56498-2.

\title{
The importance of evidence-based enhancement of the quality of learning and teaching in research-intensive universities
}

Sari Lindblom-Ylänne, University of Helsinki, Finland

Lori Breslow, MIT, US

\begin{abstract}
This chapter explores the role of research in improving teaching and learning in research-intensive universities. Over the past decades, there has been a notable increase in number studies investigating college-level teaching and learning, both in general and in specific disciplines. Pedagogical practice no longer has to be based on anecdote or intuition. Empirical evidence can inform instructions about methods that lead to better learning. The chapter presents four cases studies from the University of Helsinki and from the Massachusetts Institute of Technology that describe how careful research into pedagogy contributed to improvements in educational practice in those two universities. The chapter concludes with observations about the role educational research can play in how faculty can make informed and strategic decisions about teaching and learning.
\end{abstract}

\section{x.1 The problem at hand}

As the introduction to this book makes clear, universities are commonly seen as the jewel in the crown of nation states. This holds true for countries across a broad range of political and economic spectra, ideologies, and social systems. On the national level, higher education is considered to be one of the primary drivers of innovation, a robust economy, and a better standard of living. For the individual, an advanced degree leads to greater social mobility, material comfort, and higher social status- benefits that tend to extend generationally. In all geographic regions and for countries at all levels of development, higher education is seen as a pivotal institution in advancing the strength of the nation and improving the lives of the citizenry. 
At the same time, in many places, higher education, as an institution, is being subjected to increased scrutiny. There is more pressure on colleges and universities to meet a variety of needs than any other time in the post-World War II era. The nature and degree of criticism may vary by region, but, in general, universities are expected to increase capacity and quality, often with fewer resources at their disposal. Although higher education has always been subject to economic, political, and social forces (Perkins 2007), heightened expectations married to dwindling economic support has become a common state of affairs for universities worldwide.

For example, in the United States, colleges and universities have been called upon to justify the high cost of tuition and the resulting debt that students have upon graduation. There is much discussion, as well, about accessibility, that is, that young people from disadvantaged social groups find it more difficult to gain entrance to university, and they graduate at much lower rates than their more advantaged counterparts. The selection process to get into top-tier institutions in the U.S. has also been criticized with calls for universities to do what they can to minimize the fierce competition that accompanies the admissions process. Conservative politicians disparage university faculty, who tend to be more liberal, and they fault norms that establish an atmosphere on campus in which there is heightened sensitivity to what may be said without impunity. In the U.S., institutions of higher education are increasingly called upon to show that they have added value to their students' lives- that their graduates have gained the knowledge and abilities that will allow them to flourish professionally and personally as members of a democratic society.

In Europe, at the beginning of this millennium, countries underwent the so-called Bologna process to increase the comparability of university degrees and to enhance students' free movement between countries. Even though some European countries, such as the United Kingdom, collect high tuition fees, there is more variation in how university education is funded and organized. In Northern European countries, like in Finland, university education is tuition free. However, there are similar pressures in Europe as in the United States to develop selection procedures that are less onerous and to ensure the development of higher-order thinking skills and professional competences in graduates to smooth the transition from university to life after graduation. Many European universities are facing increased pressures for accountability from public authorities due to the resources spent on the sector. Hence, the stress on universities to demonstrate value is present on both sides of the Atlantic. 
Universities have also had to accommodate new technologies that are challenging their role as institutions that signal who has the credentials that signify the person is educated, or, at least, has attained a certain skill set. Although massive open online courses (MOOCs), launched in 2012, never met the promise of "transforming" academia, technology is having a noticeable impact on the teaching and learning enterprise. Those concerned about the costs of a university education look to technology to help lift some of the economic burden. Instructors are experimenting with so-called blended learning models to strengthen how their students gain the knowledge and capabilities they should have upon graduation.

\section{x.2 Progress made}

At the same time that universities are more vulnerable to outside criticism, there are a myriad of examples of those working inside the academy to improve programs, policies, and pedagogies. Their aim is to design institutions that foster students' mastery of crucial knowledge and critical skills that are the foundation of the future success of those students. Many university administrators and faculty are examining their own practices to strengthen how they teach and support students so that they meet the goals society asks of them. We argue that these improvements have been the result, in large measure, of an increased respect for and interest in research into how college students learn and the pedagogical practices that foster that learning. We believe that at a time when universities are increasingly under attack and called upon to demonstrate their value, the role of evidence-based change cannot be minimized. As universities are being expected to respond to issues of cost, to validate their role as purveyors of knowledge, and to demonstrate their responsibility to create an informed citizenry, it is incumbent upon those institutions to develop an evidence-based culture around educational practice.

The idea that the improvement of university-level teaching and learning should be rooted in evidence is referred to in the literature in many different ways-sometimes the terms "research-based teaching" and "research-informed teaching" are used. We prefer to use the phrase evidence-based development of teaching and learning because it emphasises the importance of relying on empirical from a wide range of fields. These disciplines can include cognitive psychology and neuroscience, which provide general insights into learning, as well as research into how students best master specific disciplines such as physics or history. We think 
it is important to draw upon findings from a wide variety of studies because university students are diverse both in their levels of ability and in the fields they choose to pursue. Evidence-based processes are also pivotal in strengthening the value of teaching in universities such as ours in which research is often considered as more important than teaching.

While learning and teaching processes are complicated in nature, research can help identify factors that contribute to high-quality, college-level teaching and learning. In particular, it is important that decisions concerning the enhancement of pedagogical processes, assessment practices, and student support programs are based on empirical evidence derived from both general educational research and studies that are discipline specific. For example, research has systematically shown that students' intrinsic motivation, their interest in studying, as well as their metacognitive and self-regulation skills, predict success at university (e.g. Entwistle 2009; Heikkilä et al. 2012; Hidi and Renninger 2006; Parpala et al. 2010; Pintrich 2004). The findings from educational research often makes sense intuitively and can even sound self-evident, but it is important, particularly in the academy, to generate empirical evidence to confirm teachers' instincts. As another example, instructors know that inspiring and activity-based teaching practices maintain students' intrinsic motivation and interest in studying, but we have only just recently had the data to show persuasive a correlation between the use of active learning pedagogies and positive outcomes in the STEM fields (Freeman et al. 2014). Research also confirms that to enhance high-quality learning outcomes, it is important to help students take responsibility for their own learning.

Another reason pedagogical activities cannot be based on previous experiences or on intuition of the faculty only is because empirical evidence often reveals complicated interrelationships or even counter-intuitive aspects, which need to be taken into account. Research on university-level learning and teaching can very seldom give simple and straightforward answers because the phenomena are so complex. In this chapter, we provide examples of research that revealed unpredictable or counterintuitive empirical evidence. We hope to show the necessity of research-informed development of educational practices by describing cases in which research led to improvements by both university faculty and academic developers, and those advances, in turn, resulted in stronger student learning,

Finally, we argue that research in teaching and learning should be undertaken systematically: this strategy follows the principle upon which the academy is founded, namely 
that we should build on existing knowledge to further develop and deepen our understanding of phenomena. As social scientists, we realize that data alone are not always convincing, but we believe that research can provide a solid foundation for improvement in the educational enterprise, and research-intensive universities are in an excellent position to demonstrate how this philosophy can be translated into action.

This chapter provides examples from two universities for how this work is taking place: one from Europe, the University of Helsinki, and one from the U.S., the Massachusetts Institute of Technology. Although on two different continents, these institutions have used similar processes to explore how research in curriculum design, pedagogy, and support for learning can improve the very practices that are at the heart of research-intensive universities. Specifically, it describes how the University of Helsinki has used research to strengthen its curricula and teaching practices, and the support it has put into place to help students learn how to learn. In the U.S., MIT has been a leader in using technology to strengthen pedagogy, and the chapter describes a two-decade-long effort in this sphere.

\section{x.3 Theories underlying an evidence-based approach}

The theoretical framework that supports our argument for evidence-based strategies and practices connects teaching with student learning, research and the academic community (Boyer 1990; Shulman 1993). According to Rice (1992), the scholarship of teaching and learning includes three aspects: first, a capacity to create a coherent picture of what is known in the field; second, pedagogical content knowledge, which serves as a bond between content and pedagogy (Shulman 1987); and third, expertise on student learning, in particular how students create meaning and master new knowledge, skills, and habits of mind.

The scholarship of teaching and learning is considered the property of the academic community and does not belong to one individual or research team. While research is often considered more of a collaborative process that teaching, which usually takes places in the isolation of the classroom between individual instructor and students, this view has evolved as the scholarship of teaching and learning has taken hold, so that teaching activities are systematically documented and practices are shared. Kreber (2002, 2013), for example, writes persuasively about the scholarship of teaching and learning as a collaborative learning process 
that strengthens the teacher community. Instructors engaging in the scholarship of teaching and learning share their work with colleagues, communicate the results in relation to research literature, and publish it in peer-reviewed journals (Hutchings \& Shulman 1999; Pyörälä, Hirsto, Toom, Myyry \& Lindblom-Ylänne 2015; Shulman 1987). Teacher-scholars can communicate their research in many different ways from peer-reviewed articles to scholarly teaching portfolios, academic developmental activities, or public presentations with peers.

The institution plays a role as it provides opportunities, in a variety of ways, for teachers to talk about their practice, critique one another, and strengthen the overall enterprise. As other chapters in this book describe in detail, these institution-wide activities can include building teaching academies, inviting experts in the scholarship of teaching and learning to speak, organizing and underwriting teaching awards, and/or developing incentive structures that reward scholarship and innovation in teaching and learning. The institution can go a long way to create and nurture a community of teachers who together identify future directions for evidence-based practices and put into place structures that will help the institution to achieve those goals.

The model created by Trigwell, Martin, Benjamin and Prosser (2000) created for the scholarship of teaching and learning is particularly compelling. Based on previous literature and teacher interviews, it comprises four dimensions: The conception dimension reflects teachers' conceptions of teaching and learning; the informed dimension describes the extent to which teachers engage with research on teaching and learning at the university, particularly that of their own disciplines; the reflection dimension illustrates the level of instructors' reflection on their teaching practices and on how well students learn in the context of their own disciplines; and the communication dimension involves the quality of communication and dissemination of both theory and practice. Findings can be shared with other scholars, or, more generally, with other stakeholders in the educational enterprise, including senior leadership, parents, policy makers, and the students themselves.

We have built the research studies we describe in the following sections on these conceptions of the scholarship of teaching and learning. The processes we have used mimic applied research in the social sciences: that is, we begin by defining a question, and then we identify methods by which data are collected, undertake the analysis, and disseminate results. But one way in which the scholarship of teaching and learning differs is that it often springs from instructors' commitment to examine their own practice and the courage to disclose findings- 
whatever they are-with the larger community. This work also differs from other social science research in that the researchers are often studying their own institutions. Whether it is the individual instructor exploring his or her own classroom or the institution looking at its practices and policies, we admire and are grateful to colleagues who are willing to explore their own efforts in order to improve how we educate university students.

\section{x.4 Strengthening curriculum design and learning support at the University of Helsinki}

The University of Helsinki in Finland is a multidisciplinary university of 36,000 Bachelor, Master and doctoral students. As defined in the Bologna declaration, the target times for graduation are three years for Bachelor, two for Master and four for Doctorate. In the strategic plan for the years 2017-2020, the vision of the University for 2025 is "Global impact in interaction", and the three main strategic aims are "A creative international environment for learning and top-level research," "Focus on the student," and "Resources for reform." The University of Helsinki is composed of 11 faculties: Agriculture and Forestry, Bio- and Environmental Sciences, Educational Sciences, Humanities, Law, Medicine, Pharmacy, Science, Social Sciences, Theology and Veterinary Medicine. In Finland, all university education from Bachelor to $\mathrm{PhD}$ is tuition free. In addition, the students receive government-financed study grants if they earn $75 \%$ of the required yearly credits. Students are selected to programs using their scores on discipline-specific entrance examinations and taking into account their national matriculation examination grades. Therefore, the average drop-out rate of students at the University of Helsinki is low. However, study progress is not regulated and students on average take more than the expected three years for a Bachelor and two for a Master's degree. There are no major consequences for the students if they take a longer than expected time to finish their degree until they are in their seventh year of study. In addition to the tuition-free education, a student status brings many advantages, such as healthcare and discounts on fares in the public transport system.

As mentioned previously, the University of Helsinki systematically uses research to strengthen its curricula and teaching practices, and to enhance the quality of student learning. The Centre for University Teaching and Learning is responsible for carrying out research on teaching and learning in different disciplines and this research is used to inform the University in 
its strategic decision-making processes. The Centre also organises different courses on teaching, learning, assessment and academic supervision and supports program leaders to enhance the quality of teaching and the learning outcomes of the students. The Centre is funded by the University's central funds. Sari Lindblom-Ylänne has been the director of the Centre since 2004. The two cases below provide examples of research-informed improvement in teaching and learning.

\section{x.4.1 Case 1: Evidence-based curriculum development in veterinary education}

The first case explores the complex relationship between experiences of the teaching-learning environment, stress and workload, and describes the effect of empirical evidence on curriculum design and teaching. The Centre of University Teaching and Learning is responsible for systematically researching and developing a HowULearn questionnaire, under the direction of Dr. Anna Parpala beginning in 2005 (e.g., Hailikari \& Parpala 2014; Parpala, Asikainen, Ruohoniemi \& Lindblom-Ylänne in press; Parpala, Lindblom-Ylänne, Komulainen, Litmanen \& Hirsto 2010; Parpala, Lindblom-Ylänne, Komulainen \& Entwistle 2013).) HowULearn is implemented through software that was developed specifically for its use so it also provides a way to collect and assess student feedback. The main idea is to enhance students', teachers' and administrators' awareness of the learning processes and how those processes are related to students' experiences of academic quality. Therefore, HowULearn is simultaneously a reflection tool for students and a way to collect data systematically for quality-enhancement processes (Parpapa \& Linblom- Ylänne 2012). Moreover, because of the instrument's strong theoretical background, it can be used for research purposes.

The HowULearn questionnaire contains four sections: 1) students' engagement, operationalized by measuring time and effort management (i.e., how students invest time and effort in their studies in order to reach high-quality learning outcomes; 2) students' self-efficacy beliefs (i.e., their beliefs in their own ability to complete tasks and reach goals (e.g. Bandura, 1977); 3) study-related exhaustion (i.e., students' experiences of a lack of emotional energy and tiredness due to high demands and workload in studying (Schaufeli, Martinez, Pinto, Salanova \& Bakker 2002); and 4) students' experiences of academic quality, for example, constructive alignment (Biggs 1996), peer support, feedback and the development of academic thinking skills 
and work-life competences. Each university student fills in the HowULearn questionnaire using the software three to four times during their university studies: after the first study year, at the end of their Bachelor studies and at the end of their Master studies. Filling in the questionnaire is a requirement in the Bachelor Orientation Studies and part of the Personal Study Plan course (one for the Bachelor and another one for the Master studies). The same questionnaire is also used in doctoral education, but with a slightly different set of scales.

After filling out the questionnaire, the students receive personal feedback and advice through the HowULearn software about how to develop their study skills and to enhance their academic success. The feedback includes the student's own scores and a group-level average score, as well as instructions about how to interpret scores. The feedback varies on the basis of the student's scores, and students with high, low or average scores compared to the whole group will receive different interpretations of their answers and different kinds of advice. These interpretations are written by study psychologists and experts in student learning. Students are able to enter the feedback on the scores they received whenever they want using their own student portal.

For individual programs, group-level data are used to enhance the quality of teaching and learning. The system allows the institution to follow up-to-date input from the students' own portals, and the institutions can also enter the group-level data whenever they need without, of course, the ability to identify individual students. Furthermore, there is an opportunity to filter and combine results to compare different study years and study programs, for example. The system also provides reports, which can be used to share aggregated data, including histograms and bar graphs illustrating student responses, with a variety of stakeholders. Finally, the data can be exported for research purposes and linked to the information regarding students' background information and study success. However, data will only be used for research with student consent.

HowULearn data from all programs at the University of Helsinki $(\mathrm{N}=2509)$ showed that veterinary students' experiences of academic quality were the most positive, but at the same time they experienced high study-related burnout (Parpala et al. 2010). This was also clearly shown in student interviews during their second study year (Mikkonen, Ruohoniemi \& LindblomYlänne, 2013). Students who were very interested in the field and motivated to study at the beginning of their program had begun to doubt their enthusiasm for the field as a result of a 
hectic study schedule. Many students complained that the heavy workload did not give them enough time and opportunity to concentrate on their own areas of interest. One of the students even doubted whether her interest had disappeared altogether as the following quote shows:

Now and then I feel horrible and I'm afraid that this does not interest me after all. I don't know why I feel like this. Maybe it's because there's no time to bury yourself in any subject, as the timetable forces you to read fast and makes you try to take in all that you have to read.

A detailed analysis of students' perceptions of the teaching-learning environment (Haarala-Muhonen, Ruohoniemi, Katajavuori \& Lindblom-Ylänne 2011) and of factors enhancing and impeding their studying showed that workload, study activities and assignments were unevenly distributed across the academic year (Ruohoniemi \& Lindblom-Ylänne 2009). In addition, veterinary students' engagement through time and effort management and their engagement in searching for understanding and creating meaning were explored (Ruohoniemi, Parpala, Lindblom-Ylänne \& Katajavuori 2010). These research results led to the reform and reorganization of the veterinary curriculum. In the new curriculum, courses were distributed more evenly across the academic years to avoid an extensive workload. The content of courses and assignments were also analyzed to ensure that the number of credits from individual courses was aligned with actual work required to pass the courses.

On the basis of the group-level follow-up data of the HowULearn questionnaire, the veterinary school was able to monitor how the curriculum reform affected study-related burnout and how the students experienced the workload. There was a clear improvement in how the students experienced the workload, which demonstrated that the curriculum reform had indeed been successful. In 2014, the HowULearn data showed that more than two-thirds of all veterinary students found the workload appropriate. The Faculty had worked for a decade to reach this goal. (Faculty of Veterinary Medicine, University of Helsinki, Annual Report 2014. http://blogs.helsinki.fi/vetmed-annualreport-2014/.) In addition, the veterinary students were encouraged to reflect upon their HowULearn inventory results and the feedback they had received in their Bachelor portfolios. The Faculty also organised feedback sessions in which the students' HowULearn results were discussed among the students and teachers. 


\section{x.4.2 Case $2 \quad$ Evidence-based development of teaching methods and study practices}

The second case examines the relationship between how students experience challenge and the quality of the processes they use to study. The massification of higher education particularly in Europe during the last decades has increased the diversity of the student population (GuriRosenblit, Šebková \& Teichler 2007). While some students proceed and succeed in their studies without difficulty, some regularly confront problems in passing courses and fail to reach the expected learning outcomes. Large variation in students' knowledge and skills poses challenges for university teachers in designing courses and selecting effective teaching methods to help all students successfully complete their studies. Students need to be able to choose study strategies that will help them successfully pass their courses.

Postareff and colleagues (Postareff, Lindblom-Ylänne \&Parpala 2014; Postareff, Parpala \& Lindblom-Ylänne 2015) explored the study processes of Bachelor students representing a variety of disciplines at the University of Helsinki. In these studies, a mixed-method approach was applied: the students filled in the HowULearn inventory measuring their study processes and experiences of the teaching and learning environment at the beginning and at the end of a course. In addition, students were interviewed after the course about their personal study aims, motivation and interest, study processes and practices, as well as their experiences studying in the course. The results showed that when students experience both a high level of challenge and a lack of challenge, they are pushed to superficial learning. When students are challenged too much, they start doubting their skills and knowledge, which weakens their self-efficacy beliefs and results in surface learning and fragmented knowledge. This, in turn, results in a vicious circle of procrastination in which students delay studying with harmful consequences (LindblomYlänne, Saariaho, Inkinen, Haarala-Muhonen \& Hailikari 2015). Further, Lindblom-Ylänne et al. (2015) showed that procrastinating students experienced more negative academic emotions, were less motivated to study, and showed weaker self-efficacy beliefs. For this study, slowly progressing bachelor students in humanities and law were interviewed after their first study year. (Here, slowly progressing students refer to those who failed to achieve the required number of credits during their first year. In the Finnish university system, these students can possibly 
continue their studies despite the slow beginning.) In the following quote, a procrastinating student explains how she studies and her experience of university:

From primary to upper secondary school I was a really good student, but now I feel that I can't learn anything about any topic. This depresses me. I don't have enough time to really learn something, and that feels bad. Maybe I'm aiming too high, and when I can't reach my aims, I get depressed.

These results show that the students who experience a great deal of challenge need individual support and advice about how to develop their time-management and study skills, how to selfregulate their learning, and how to develop efficient study strategies.

However, a lack of academic challenge has as severe a consequence as too much challenge. Students who lack challenges lose their motivation to study, do the minimal amount of work, and invest their efforts where they are able to find interesting and inspiring assignments (Postareff et al. 2015). For example, one mathematics student felt that one compulsory course did not provide much new information and, therefore, he decided not invest time and effort in studying the content, as the following quote shows:

My aim was to pass the course; I wasn't aiming at high grades. I did not have the energy to overachieve. I attended the lectures and took notes. However, I did not do many exercises, maybe some - two, I think. Neither did I participate in the optional counselling sessions. This was maybe bit stupid; I could have learned there. I also could have been more active, but this was how it went. Let's say that my sleep cycle impeded studying.

Feedback from university teachers who take the extensive number of pedagogical course that he University of Helsinki organises (e.g. Postareff, Lindblom-Ylänne \& Nevgi 2007; Postareff, Lindblom-Ylänne \& Nevgi 2008) shows that because of the increased variation in students' knowledge and skills, teachers often are concerned with students who struggle with their studies. In response, teachers are likely to design their course content and assignments to meet the knowledge and skills of the weaker students. In the courses on university teaching, the teachers are given support to select teaching methods and design learning activities that enable meaningful study experiences for students with different levels of knowledge and skills. In addition, the teachers are advised about using formative assessment as well as peer- and self-assessment to support the learning processes of the 
students. Furthermore, in these pedagogical courses, the teachers discuss how to design group activities and how to mark group work in heterogeneous groups.

On the basis of the empirical evidence, the University of Helsinki has developed student-support practices to better serve the diverse student population. For example, licenced study psychologists, i.e. clinical psychologists, who are specialists in learning difficulties in university students, offer individual support for students who struggle with study-related problems. Study psychologists also organise group-level courses on various topics, such as academic writing, study skills, procrastination, and reducing study-related burnout and stress. The study psychologists collaborate closely with the Centre for Teaching and Learning in order to support the students' study processes in the best possible way. The close interaction between the study psychologists and the Centre enables the creation of a strong link between educational research and the development of learning and teaching practices at the university. In addition, study psychologists participate in many of the Centre's research projects (e.g., Lindblom-Ylänne et al. 2015; Mikkonen et al. 2013). It is important to explore the effects of support and counselling services provided by the study psychologists, because the development of the services the study-psychologists provide also need to be based on empirical evidence.

\section{Improving conceptual understanding and reducing failure in physics at MIT}

As its name implies, the Massachusetts Institute of Technology is an institution devoted to science and engineering. Its motto, "Mens et Manus" (mind and hand), is meant to reflect its focus on both intellectual and practical education. Currently, it enrolls approximately 4,200 undergraduates and 6,000 graduate students at both the Master's and doctoral level. It is composed of five schools, including Science; Engineering; Humanities, Arts and Social Science; Architecture and Urban Planning; and the Sloan School of Management. The School of Engineering has the largest number of undergraduate majors with the Department of Electrical Engineering and Computer Science graduating approximately 40 percent of students. As many top-tier universities in the U.S., tuition and fees are extraordinarily expensive at US\$48,452 for the 2016-2017 academic year. Adding room, board and supplies, and the average cost for an undergraduate per year at MIT is US\$65,500. But MIT follows what is known as a needs-blind 
admissions policy, meaning that the staff who make selection decisions do not know the economic status of the students they are evaluating for admissions. MIT guarantees that upon admission, the Institute will find ways to underwrite a good portion of the fees. In 2015-2016, MIT undergraduates who did take out loans (28 percent) owed an average debt of under US $\$ 25,000$. This was 15 percent less than the national average in 2014 , which was just under US\$29,000 (http://sfs.mit.edu/access-affordability/affordable-mit).

All undergraduates are admitted to MIT — not to an individual school or department. In order to graduate, all students must complete the General Institute Requirements (GIRs), which constitute about half of the curriculum over the four years. The GIRs include a very rigorous science core composed of two courses in physics, two courses in calculus, and one course each in biology and chemistry. Most, but not all, of the students complete the science core in their first year. The remainder of the General Institute Requirements are comprised of courses in the humanities and social sciences, restricted electives in the sciences, and a laboratory course. Additionally, students must complete two communication-intensive courses in the humanities (e.g. literature or history) and two communication-intensive courses in their majors.

\subsection{Case 3: Technology-Enabled Active Learning (TEAL) Phase I}

In 1999, faculty and instructors in the physics department at MIT made a decision to tackle what had been a long-standing problem: the failure rate in first-year physics. Historically, the two required physics courses, one in mechanics and one in electricity and magnetism, had been taught in a lecture/recitation format (as are all the courses in the science core). In this format, students typically went to two lectures a week with 800 of their classmates, and then met once in a week in a smaller class of 15 to 20 students, on average. The recitation could be taught by a faculty member or a graduate student. Often, the recitation instructor solved problems for the students that resembled the problems that were on their homework assignments for that week.

While each of the science core courses was difficult, the failure rate for the two physics courses, mechanics (semester 1, which is known by its course number, 8.01) and electricity and magnetism (semester two, 8.02), was particularly high. On average, 10 percent of the students would fail, but often the number was as high as 15 percent. The department of physics was concerned about that situation, as were members of the MIT senior administration. Prior to 1999, 
several different pedagogical experiments had been tried, but they were not successful in decreasing the percent of failures.

Then a team led by physics faculty member John Belcher began to explore a more radical innovation in how first-year physics would be taught. That method, which was based on interactive instruction supported by various kinds of technology, would follow a set of reforms undertaken by other universities (most notably Rochester Institute of Technology and North Carolina State University). The MIT version of studio physics was named TEAL; the acronym stands for Technology Enabled Active Learning. The essence of TEAL is that students do something to help them understand a topic; the instructor does not lecture but only provides a short (10-15 minute) explanation. Then the students might perform a desk-top experiment, view an animation or simulation and answer questions, analyse data, or work out a problem. In the TEAL format, students work at round tables in groups of three on these activities with instructors and teaching assistants available to answer any questions the students may have. Students are sometimes asked to present the work they have done to the class as a whole. Much of the financial support for TEAL came from the d'Arbeloff Fund for Excellence in Education, a fund established at MIT by the then-Chairman of the MIT Corporation and his wife, Alex and Brit d'Arbeloff, in 1999 (http://web.mit.edu/darbeloff/). This included building a classroom designed specifically for this pedagogy. Since the TEAL classrooms can accommodate between 80-110 students, video cameras, white boards, and screens have been placed around the room so all the students have access both to the instructors' materials, as well as to their own work.

TEAL was piloted twice at MIT in 2000 and 2001. In academic year 2002-2003, students were taking electricity and magnetism (8.02) both in the traditional format (i.e., lecture/ recitation, fall 2002) and in TEAL (spring 2003). This provided educational researchers with an excellent opportunity to compare the efficacy of the two pedagogical methods. A pre-test/posttest design was implemented with the faculty member teaching in the traditional format $-\mathrm{a}$ world-renown lecturer - approving the tests and agreeing that they reflected the rigor of an MIT course. Results showed that students in the TEAL format made statistically significant learning gains in relation to the students who studied electricity and magnetism in the lecture/recitation mode.

The results were particularly striking because they countered a perception held by several physics faculty members (although it is probable this view was believed more widely within the 
faculty) that the TEAL pedagogy would be most beneficial for students who were less prepared or weaker in physics. In order to explore this belief, the researchers (Dori \& Belcher 2005) split the group of students in both courses into thirds—low, intermediate, and high — based solely on their pre-test scores. As Figure 1 indicates, each group of students in both TEAL and the lecture/recitation mode improved from the pre-test to the post-test, but all three groups of TEAL students showed higher learning gains than their counterparts who took the course in lecture mode.

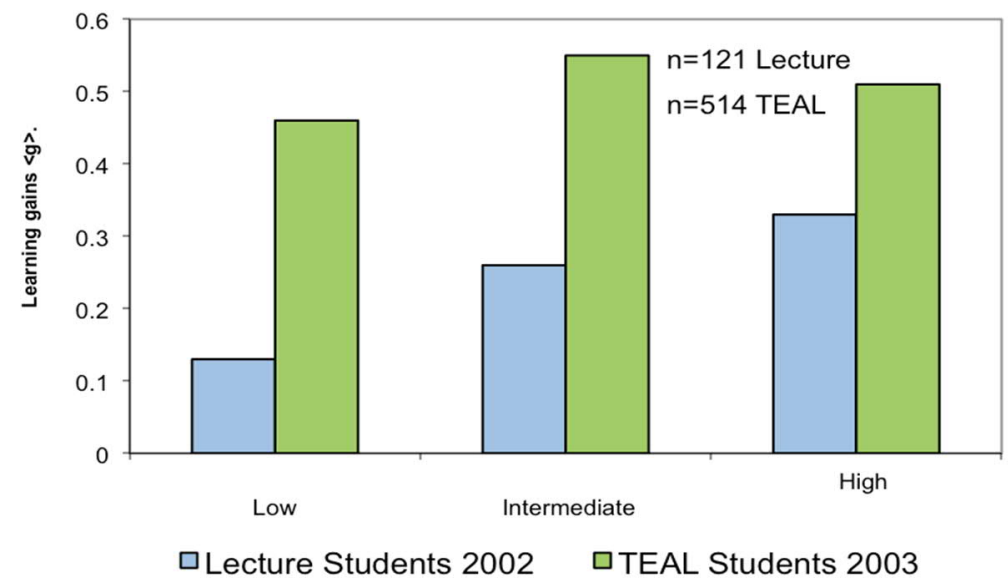

Fig. x.1: Comparison of pre-test and post-test learning gains for students who took electricity and magnetism in a lecture/recitation format and those who studied in an interactive classroom model.

Subsequently, the researchers followed a subgroup of this cohort of students (i.e., who took electricity and magnetism in both pedagogical models) to assess how much of their learning was retained; they wanted to know if the TEAL students continued to demonstrate stronger results. (Many educational theorists, researchers, and policy makers hold that the ability to transfer and retain conceptual knowledge is the most important outcome of higher education. See, for example, Halpern \& Moskel 2003; Pellegrino \& Hilton 2012.) The students who took the retention test 12-18 months after completing electricity and magnetism were specifically selected because their major would require them to use E\&M concepts. As Figure 2 indicates, although the gap closed between the TEAL students and the student who took the course in lecture/recitation format, the TEAL students still scored higher on the retention test. Finally, a review of student success pre-TEAL and post-TEAL for the graduating classes 2006-2013 
revealed that the percent of students who received below a $\mathrm{C}$ grade in mechanics dropped from 7.5 percent to 6.3 percent ( $\mathrm{p}=.042)$ (O’Leary 2010).

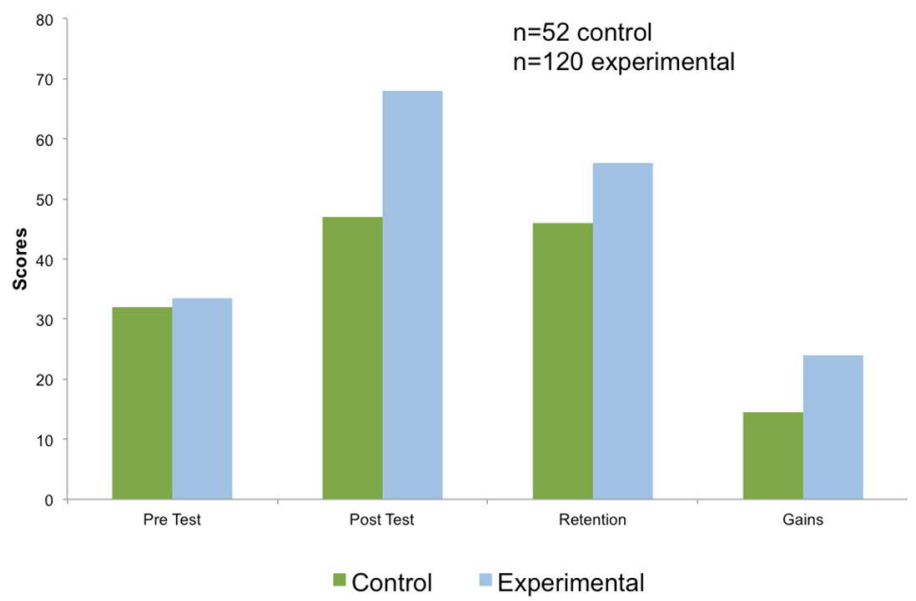

Fig. x.2: Comparison of pre-test, post-test and retention test learning gains for students who took electricity and magnetism in a lecture/recitation format and those who studied in a studio physics model.

Although research showed better learning gains in TEAL, student criticism of the change in teaching began when TEAL went to full-scale implementation in 2003, and continued intermittently over the next several years. The major complaint was that in order to receive the highest possible grade in the course (an "A") students had to go to class since points were awarded for in-class exercises and activities. This countered the norms at MIT for the science core courses; although nominally students were to go to lectures, in fact, there were no overt penalties for not attending (Breslow 2010; Hastings \& Breslow 2015). By necessity, MIT students are very good at optimizing their time, and they resented the fact that there was an expectation they would be in TEAL classes. The response was particularly surprising because in the first semester, student grades are only entered as either "Pass" or "No Record." In other words, whether students receive an A or a lower grade does not appear on their transcript as long as they pass the course. 
Nonetheless, in response to the complaints, the head of the physics department convened a committee to review TEAL in 2007, asking committee members to make a recommendation as to whether or not it should be continued. The committee met through the year, and, while there was a good deal of debate within the committee, it ultimately recommended continuing to teach first-year physics in the TEAL format. That continues to be the case as of this writing; almost all MIT students take both mechanics and electricity and magnetism in the TEAL format. The research that demonstrated learning gains for both first-year and upper class students was important in making the case that the pedagogy and technology that TEAL employed with instrumental in its success.

\subsection{Case 4: TEAL improved through the use of additional technology}

In 2012, several of the faculty and instructional staff who originally developed TEAL came together to develop two massive open online courses (MOOCs), one in mechanics and one in electricity and magnetism, to be hosted on the edX platform. (MIT and Harvard had launched edX, their answer to the Stanford-based MOOC developer, Coursera, in 2012.) It was assumed early in the organization of edX that introductory courses in physics from MIT could have a large following, and, in fact, the then-chair of the physics department appointed an ad hoc committee, the PhysicsX Planning Group, to identify and subsequently monitor departmental courses that would be developed for and hosted by edX. It took approximately nine months for the instructional team, along with developers and educational technology specialists from edX, to develop the first of the two MOOCs, electricity and magnetism (8.02x). The course went live in February 2013. It lasted 14 weeks, mimicking the length of a semester at MIT and ending in June 2013. The course consisted of lectures, an e-textbook, recorded help sessions to aid students with the homework questions, a discussion forum, and simulations and visualizations. Students had to answer a set of questions after finishing a lecture before they were allowed to go on to the next. Homework was due after every three lectures, and grades were based on the homework, three exams and a final. The mechanics course followed in September 2013 (Belcher 2013).

Over 43,000 people registered for 8.02x over the 14-week period, but only 1,715 enrolees completed the course. This high attrition rate mirrors what had been seen in MOOCs courses published on both edX and Coursera in the first years after their launch (Breslow, Pritchard, 
DeBoer, Stump, Ho \& Seaton 2013; MOOCs at Edinburgh Group 2013; Perna, Ruby, Boruch, Wang, Scull, Evans, \& Ahmad 2013). In fact, it could be argued that by 2015 the rhetoric around MOOCs, which claimed they would transform education (Pappano, 2012), had mellowed significantly. MOOCs providers began to focus attention on how online courses could best meet the professional needs of students primarily in computer science and business.

But as early as 2013, Belcher wrote, "We plan to experiment with completing 'flipping' 8.02 TEAL for two to three weeks in the coming academic year [spring 2014], using the capabilities of the edX platform to deliver the online content" (p. 14). He explained that the team would assess the class by getting feedback from both student and faculty and by assessing the gains in student learning. In this way, he was promising to explore the field's understanding of flipped or blended classrooms in which both face-to-face pedagogy and technology are used in some proportion to teach. In fact, we know relatively little about what those proportions should be, or what each mode of delivery does best, depending on the students, the discipline and the instructional goals (Lack 2013; Zhou \& Breslow 2013; Bernard, Borokhovski, Schmid, Wade, Tamin, \& Abrami, PC 2014).

As it turned out, this plan was not implemented exactly as Belcher had planned. For a variety of reasons, including capacity of the staff, capability of the technology, and the learning objectives the instructors felt were most important, a different plan emerged. In the spring semester 2014, in the electricity and magnetism course (8.02), the instructional team, again working with developers and educational technologists, put most of the course resources, including recorded lectures, tutorials, and an e-textbook, on MITx, the Institute's local instantiation of the edX platform. The course retained the same on-campus format that TEAL had used since 2003: students attended two, two-hour classes per week and a one-hour session on Friday in which they worked together in teams on their homework.

But two features were added. First, students were given pre-class assignments that were due immediately before class. Links to chapters in the textbook were provided for the students, who then had to answer questions online that asked them to apply concepts from the material they had read. Questions were graded automatically and students could see the answers after they submitted theirs so they knew right away if their answer was correct. Credit for completing these assignments was based solely on effort so as long as students submitted an answer, they got full credit. 
Secondly, all the homework problems were put on the MITx platform, and the students could check their answers to each part of the problem with the Checkable Answer Feature (CAF) on the course website. If the student's answer was correct, they would see a green check mark, but if it was wrong, a red $\mathrm{X}$ would appear on the screen. Thus, they received immediate feedback, a practice that educational research cites as strengthening learning. Finally, students were asked to submit one or two homework problems online each week, which guaranteed their use of the CAF. (They could use the CAF for the handwritten problems, but they were not required to do so.) As the course developers wrote, "We hoped the checker would encourage students to focus on the process of solving the problems rather than getting the final answer" (Rayyan \& Belcher 2014, p. 12). The effort to put all course materials on the MITx platform and add the CAF was called 8.02 TEAL $+\mathrm{x}$.

Students were surveyed to get their feedback on the migration of 8.02 to the MITx platform, and over 95 percent told the course instructors that they should continue to use the platform for 8.02; 92 percent reported it should be implemented in other physics courses. Similarly, the response to the CAF was overwhelmingly positive with over 90 percent of the students saying it was "extremely helpful" or "very helpful" (Rayyan \& Belcher 2014). As Figure 3 shows, students liked it for a variety of reasons, including that it reduced their stress and increased their self-confidence when working on their homework assignments. With these

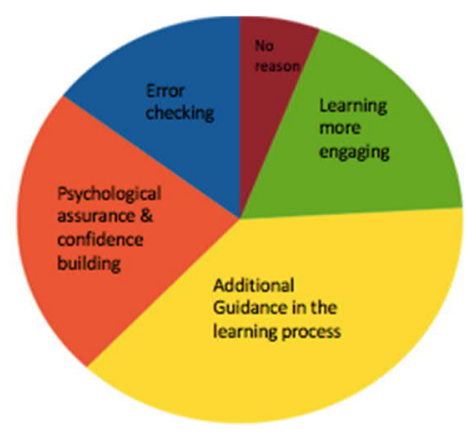

Fig. x.3: Reasons student cited for positive response to the CAF (graph courtesy of Dr. Saif Rayyan).

encouraging results, the mechanics course (8.01) migrated to the MITx platform in fall 2014.

Incorporating the MITx platform into the fall course was complemented by a research effort to analyse all the clickstream data that was generated by it use. In other words, researchers were able to capture, and then analyse, every interaction the students had with the platform. For 
the 474 students who were enrolled in mechanics in fall 2014, this could include whether they accessed an online resource, used the CAF, got the right answer to the homework on the first try, did their homework over the course of days, as well as a host of other behaviours. The result was more than 30 million browser-side and server-side interactive events, which constitute more than $8 \mathrm{~GB}$ of raw log data. This study also included a survey that asked students about their selfefficacy for studying mechanics, interviews with a sample of them, and think-aloud observations as student volunteers worked the online problems both individually and in groups. The analysis of these data is ongoing although we have been able to categorize, descriptively, student behaviours with the platform (DeBoer \& Breslow 2016). We have also identified those behaviours that correlate with achievement in the course, defined as grades on the final exam and overall course grade.

Perhaps what is more applicable to the theme of this chapter is that the research team collaborates closely with the instructional and development team so that the latter can use research results to strengthen course materials, pedagogy, technology, and, ultimately, the student experience. Educational researchers have never been able to observe student learning at the fine-grained level that an interactive platform allows, and we want to make sure that we take as much advantage of this capability as possible. In order to do that, the research team, under the leadership of Professor Jennifer DeBoer of Purdue University, have developed several "products" for use in the class. For the fall 2015 students, they wrote a "study guide" that summarized what they have seen are useful study strategies. Next, they designed an online guide designed to be incorporated into the website that tells students the resources that are available to them. At the same time, they created a slide-based video that describes for students ways in which they can interact with the platform that seem to lead to more success in the course. As of this writing, the course instructional team has been so busy teaching the course and making improvements on the website that they have not had time to use either product. Such is the reality of educational innovation, particularly when it involves technology: good ideas flow more quickly than can be implemented. The goal is to make both the online guide and the video available to students in spring semester 2017.

\section{Conclusion}


This book is organized around three major challenges that research-intensive universities face when attempting to strengthen the education they provide their students. The normative challenge relates to the practices and policies university administrators and faculty have put in place that sustain — or perhaps constrain—how teaching and learning is carried out at the institution. The normative challenge defines how the education and research functions of the university relate to one another, how each is practiced, and how each is valued. Established policies and norms are intertwined with the second challenge, practice, which asks how faculty can be encouraged to implement pedagogical methods and assessment techniques that foster learning. How can these methods become the accepted standard? What policies around faculty promotion and compensation lead to the institutionalization of best practices in teaching and learning? Finally, the organizational challenge requires that we accept that if teaching and learning are to be strengthened at research-intensive universities, decisions must be made at the organizational level about how this change is to infiltrate the entire institution and who will be responsible for driving it forward. As these cases describe, research projects are instigated by different people, groups, levels of seniority at both institutions. We believe this practice has been beneficial and should continue as a way forward.

We believe that research on teaching and learning and the empirical evidence that is the result can make a substantial contribution to meeting each of these three challenges. We might even go so far as to say that decisions about how to overcome these challenges need to be based primarily on the empirical evidence. Experts in the disciplines that are showcased in this chapter-researchers in veterinary medicine and physics, for example-would never begin a line of research in their laboratories without being aware of current findings in their field. They take as a given that their job is to push the boundaries of knowledge, building on what is already known. Why should the academy approach the educational enterprise in any other way?

The cases described in this chapter show that empirical evidence on teaching and learning leads to a broader and deeper picture of the complex interaction between learning, teaching and the teaching-learning environment. Rigorously derived findings can point to strengths and weakness in teaching and learning practices and processes. In becoming aware of what is working and what is not, we can more effectively tailor development activities to overcome current weaknesses and build on current strengths. Research can unpack reasons for educational problems that may seem intractable, but with careful exploration, solutions to those problems can 
be found.

We believe that the cases presented in this book are examples of the approach and processes that lead to findings that can be used to make informed decisions about best practices in teaching and learning at the university level. There are now thousands of these studies done in universities worldwide. These efforts, which depend on the partnership of faculty and administrators with educational researchers, are the product of faculty and staff who have courage to look at current practices and ask the important question-can we do this better? The findings that come from well-designed, well-implemented studies do not have to be accepted wholesale because scepticism is an important part of the process. But neither should those findings be dismissed if they counter prevailing wisdom or political interests. As has been the case for centuries in the university, advances will be achieved by taking the results of scholarship and using them wisely. The quality of university-level teaching and learning can never be taken for granted, so there is always the need for continuous research-informed development.

${ }^{1}$ Learning gains $\langle\mathrm{g}\rangle=\%$ Correct ${ }_{\text {post-test }}-\%$ Correct pre-test $100 \%-\%$ Correct pre-test

\section{References}

Bandura A (1977) Self-efficacy: Toward a unifying theory of behavioural change. Psychological Review 48(2):191-215

Belcher J (2013, September/October) The MIT physics department's experience with edX. The MIT Faculty Newsletter Vol. XXVI(1):1,12-14, available at http://web.mit.edu/fn1/volume/261/belcher.html

Bernard RM, Borokhovski E, Schmid RF, Wade CA, Tamin RM, Abrami, PC (2014) A metaanalysis of blended learning and technology use in higher education: From the general to the applied. Journal of Computing in Higher Education 26(1):87-122.

Breslow L, Pritchard DE, DeBoer J, Stump G, Ho AD, Seaton DT (2013) Studying 
learning in the worldwide classroom: Research into edX's first MOOC. Research \& Practice into Assessment 8:13-25, available at http://www.rpajournal.com/studying-learning-in-theworldwide-classroom-research-into-edxs-first-mooc/

Breslow L (2010) Wrestling with pedagogical change: The TEAL initiative at MIT. Change: The Magazine of Higher Learning 42(5):23-29

Breslow L, Johnston K, Goode D, Jacobs J (2006) The CMI Teaching \& Learning Network: A collaboration between Cambridge University and MIT. Panel presented at the International Society for the Scholarship of Teaching and Learning annual conference, Washington, D. C., 912 November 2006

DeBoer J, Breslow L (2016) Student behaviors using feedback in a blended physics undergraduate classroom. Work-in-progress paper presented L@S: The Third Annual ACM Conference on Learning at Scale, Edinburgh, UK, 25-26 April 2016

Dori Y, Belcher J (2005) How does technology-enabled active learning affect undergraduate students' understanding of electromagnetic concepts? The Journal of the Learning Sciences 14(2):243-279

Dori Y, Hult E, Breslow L, Belcher JW (2007) How much have they retained? Making unseen concepts seen in a freshman electromagnetism course at MIT. Journal of Science Education and Technology 16(4):299-323

Faculty of Veterinary Medicine, University of Helsinki, Annual Report 2014. http://blogs.helsinki.fi/vetmed-annualreport-2014/

Freeman S, Eddy SL, McDonough M, Smith MK, Okoroafor N, Jordt H, Wenderoth MP (2014) Active learning increases student performance in science, engineering, and mathematics. Proceedings of the National Academy of Sciences 111(23):8410-8415 
Goode D, Breslow L (2008) Educational change. Paper presented at the International Society for the Scholarship of Teaching and Learning annual conference, Edmonton, Alberta, Canada, 16-19 October 2008

Guri-Rosenblit S, Šebková H, Teichler U (2007) Massification and diversity of higher education systems: Interplay of complex dimensions. Higher Education Policy 20:373-389

Haarala-Muhonen A, Ruohoniemi M, Katajavuori N, Lindblom-Ylänne S (2011) Comparison of students' perceptions of their teaching-learning environments in three professional academic disciplines - a valuable tool for quality enhancement. Learning Environments Research 14(2):155-169

Hailikari TK, Parpala A. (2014). What impedes or enhances my studying? The interrelation between approaches to learning, factors influencing study progress and earned credits. Teaching in Higher Education, 19(7), 812-824.

Halpern DF, Moskel MD (2003, July/August) Applying the science of learning to the university and beyond. Change: The Magazine of Higher Learning, 36-41

Hastings D, Breslow L (2015) Key elements to create and sustain educational innovation at a research-intensive university. In:Weaver G, Slakey L, Burgess W, Childress A (eds) Transforming institutions: Twenty-first century undergraduate STEM education. Purdue University Press, West Lafayette, Indiana, p 199-207

Kreber C (2002) Teaching excellence, teaching expertise and the scholarship of teaching. Innovative Higher Education 27(1):5-23

Kreber C (2013) Empowering the scholarship of teaching: An Arendtian and critical perspective. Studies in Higher Education 38(6):857-869

Lack, KA (2013) Current status of research on online learning in postsecondary education, 
available at http://sr.ithaka.org/research-publications/current-status:research-online-learningpostsecondary-education

Lindblom-Ylänne S, Saariaho E, Inkinen M, Haarala-Muhonen A, Hailikari T (2015) Academic procrastinators, strategic delayers and something betwixt and between: An interview study. Frontline Learning Research 3(2):27-42

Mikkonen J, Ruohoniemi M, Lindblom-Ylänne S (2013) The role of individual interest and future goals during the first years of university studies. Studies in Higher Education 38(1):71-86

MOOCs@Edinburgh Group (2013, May 5) MOOCs @ Edinburgh 2013: Report \#1, available at https://www.era.lib.ed.ac.uk/handle/1842/6683

O'Leary L (2010) Student success in 8.01. Unpublished statistical analysis, MIT Teaching \& Learning Laboratory, prepared for the Office of the Dean for Undergraduate Education, Massachusetts Institute of Technology

Pappano L (2012, November 2). The year of the MOOC. The New York Times, available at http://www.nytimes.com/2012/11/04/education/edlife/massive-open-online-courses-aremultiplying-at-a-rapid-pace.html

Parpala A, Asikainen H, Ruohoniemi M, Lindblom-Ylänne S. (In press). The relationship between the development of time- and effort- management and experiences of teaching-learning environment in a university context. International Journal of Learning and Change.

Parpala A, Lindblom-Ylänne S (2012) Using a research instrument for developing quality at the university. Quality in Higher Education 18(3):313-328.

Parpala A, Lindblom-Ylänne S, Komulainen E, Entwistle N (2013) Assessing students' experiences of the teaching-learning environment and their approaches to learning: Validation of a questionnaire used in different countries and varying contexts. Learning Environments Research 16(2):201-215. 
Parpala A, Lindblom-Ylänne S, Komulainen E, Litmanen T, Hirsto L (2010) Students' approaches to learning and their experiences of the teaching-learning environment in different disciplines. British Journal of Educational Psychology 80(2): 269-282

Pellegrino JW, Hilton ML (2012) Education for life and work: Developing transferable knowledge and skills in the 21st century. The National Academies Press, Washington, DC Perkins H (2007) History of universities. In: Forest, JJF \& Altbach, PG (eds) International handbook of higher education. Springer, New York, p 159-205

Perna L, Ruby A, Boruch R, Wang N, Scull J, Evans C, Ahmad, S. (2013) The life cycle of a million MOOC users. Paper presented to MOOC Research Initiative Conference, Arlington, Texas, 5-6 December, available at http://www.gse.upenn.edu/pdf/ahead/perna_ruby_boruch_moocs_dec2013.pdf

Postareff L, Lindblom-Ylänne S, Nevgi A (2007) The effect of pedagogical training on teaching in higher education. Teaching and Teacher Education 23(5):557-571

Postareff L, Lindblom-Ylänne S, Nevgi A (2008) A follow-up study of the effect of pedagogical training on teaching in higher education. Higher Education 56(1):29-43

Postareff L, Lindblom-Ylänne S, Parpala A (2014) Explaining university students’ strong commitment to understand through individual and contextual elements. Frontline Learning Research 3:31-49

Postareff L, Parpala A, Lindblom-Ylänne S (2015) Factors contributing to changes in a deep approach to learning in different learning environments. Learning Environments Research $18: 313-333$

Pyörälä E, Hirsto L, Toom A, Myyry L, Lindblom-Ylänne S (2015) Significant networks and meaningful conversations observed in the first-round applicants for the Teachers' Academy at a 
research-intensive university. International Journal for Academic Development, 20(2): 150-162

Rayyan S, Belcher J (2014, November-December) 8.02 TEAL+x: Students say "yes" to MITx in 8.02 TEAL. The MIT Faculty Newsletter Vol. XXVII(2):12-14, available at http://web.mit.edu/fnl/volume/272/fnl272.pdf

Rice R (1992) Towards a broader conception of scholarship: The American context. In: Whiston, T, Geiger, R (eds) Research and higher education: The United Kingdom and the United States. SRHE and Open University Press, Buckingham, p 117-129

Ruohoniemi M, Lindblom-Ylänne S (2009) Student perspectives on factors enhancing and preventing their learning. International Journal for Academic Development 14(1):69-81

Ruohoniemi M, Parpala A, Lindblom-Ylänne S, Katajavuori N (2010) Relationships between students' approaches to learning, perceptions of the teaching-learning environment, and study success - a case study of third-year veterinary students. Journal of Veterinary Medical Education, 37(3):282-288

Schaufeli WB, Martinez IM, Pinto AM, Salanova, M, Bakker AB (2002) Burnout and engagement in university students: a cross-national study. Journal of Cross-Cultural Psychology 33(5):464-481

Seering W, Hall S, Britter R, Breslow L, Mitchell R (2005) An intercultural experiment in pedagogy: MIT adapts the University of Cambridge's small-group teaching model. Poster presented at the Center for the Advancement of the Scholarship of Engineering Education annual meeting. Indianapolis, Indiana.

Shulman LS (1987) Knowledge and teaching. Harvard Educational Review, 57(1):1-22

Singer SR, Nielsen NR, Schweingruber, HA (eds.) (2012). Discipline-based education research: Understanding and improving research in undergraduate science and engineering. The National 
Academies Press, Washington, D. C

Zhoa Y, Breslow L (2013). Literature review on hybrid/blended learning, available at http://tll.mit.edu/sites/default/files/library/Blended_Learning_Lit_Review.pdf 